\title{
MODIFIKASI SAPUTANGAN MENJADI BENTUK PRODUK PERTANIAN UNTUK SOUVENIR PENGANTIN MELAYU DI KELURAHAN RUMBAI
}

\author{
Surtinah $^{1 *}$, Vita Amelia ${ }^{2}$, Asgami Putri ${ }^{3}$ \\ 1*Prodi Agroteknologi, Fakultas Pertanian, Universitas Lancang Kuning, Pekanbaru, Indonesia \\ ${ }^{2}$ Prodi Ilmu Perpustakaan, Fakultas Ilmu Budaya, Universitas Lancang Kuning, Pekanbaru, Indonesia \\ ${ }^{3}$ Prodi Agribisnis, Fakultas Pertanian, Universitas Lancang Kuning, Pekanbaru, Indonesia \\ *Penulis Korespodensi: surtinah@unilak.ac.id
}

\begin{abstract}
Abstrak
Pekanbaru merupakan salah satu kota yang penduduk aslinya adalah suku melayu. Sehingga seluruh kegiatan yang dilakukan dalam prosesi kelahiran, pernikahan sampai kematian akan dialaksanakan sesuai dengan adat istiadat melayu. Pada prosesi pernikahan, masyarakat melayu di kota memberikan souvenir yang lebih beragam, dan melalui kegiatan pengabdian masyarakat ini diharapkan souvenir yang diberikan sesuai dengan adat melayu dan sesuai dengan kompetensi keilmuan Tim pelaksana. Target kegiatan PKM ini adalah mitra mampu memodifikasi saputangan handuk ke dalam bentuk produk pertanian yang dapat digunakan sebagai souvenir pengantin melayu. Kegiatan dilaksanakan pada kelompok Salimah di Kelurahan Rumbai pesisir Kota Pekanbaru pada tanggal 13 Desember 2017, jumlah peserta yang mengikuti kegiatan ini sebanyak 32 orang. Metode yang digunakan adalah penyadaran/penyuluhan, demonstrasi, uji coba, dan evaluasi. Hasil kegiatan yang diperoleh adalah $80 \%$ peserta meningkat pengetahuannya tentang pembuatan souvenir pengantin melayu.
\end{abstract}

Kata Kunci : Souvenir, saputangan handuk, modifikasi, produk pertanian, melayu

\begin{abstract}
Pekanbaru is one of the cities where the original inhabitants are Malay. So that all activities undertaken in the procession of birth, marriage to death will be executed in accordance with the Malay customs. In the procession of marriage, people in Malay city provide more diverse souvenirs, and through community service activities is expected souvenirs are given in accordance with customary Malay and in accordance with the scientific competence of the Implementing Team. Target of this PKM activity is partner able to modify handkerchief of towel into the form of agricultural product that can be used as souvenir of Malay bride. The activity was carried out at Salimah Group in Rumbai Urban Village Pekanbaru City on December 13, 2017, the number of participants who follow this activity as many as 32 people. The methods used are awareness / extension, demonstration, trial, and evaluation. The result of the activity is $80 \%$ of participants increase their knowledge about making souvenir of Malay bride.
\end{abstract}

Keywords: Souvenir, handkerchief towel, modification, agricultural product, Malay

\section{PENDAHULUAN}

Pekanbaru merupakan salah satu kota yang penduduk aslinya adalah dari suku melayu. Sehingga seluruh kegiatan yang dilakukan dalam prosesi kelahiran, pernikahan sampai kematian akan dialaksanakan sesuai dengan adat istiadat melayu. Dalam acara pernikahan, suku melayu yang ada di Pekanbaru sering membekali para tamu undangan dengan souvenir, pada acara pernikahan yang dilaksanakan di pedesaan, biasanya souvenir pengantin diberikan dalam bentuk telur yang dimasukkan dalam satu wadah berhias. Sedangkan pada pernikahan masyarakat melayu yang ada di perkotaan, maka souvenir pengantin diberikan dalam berbagai bentuk souvenir yang banyak diperjual belikan di pasar.
Souvenir pengantin dapat dikatakan sebagai gambaran kondisi prestise dari tuan rumah penyelenggara resepsi. Oleh karena itu souvenir pengantin menjadi suatu yang tak dapat dipisahkan dalam penyelenggaraan acara resepsi pernikahan masyarakat melayu di Pekanbaru (Syahrani dan Fatimah, 2015).

Persiapan dalam menyediakan souvenir pengantin melayu memerlukan anggaran khusus, tergantung dari kemampuan penyelenggara hajatan tersebut. Masyarakat umumnya membelinya di pasar, namun souvenir yang diperjual belikan di pasar sering tidak memenuhi keinginan pembeli yang akan menyelenggarakan acara resepsi pernikahan tersebut (Sungkowo, 2008). 
Tuan rumah penyelenggara acara semampu mungkin akan menghormati tamu yang hadir dengan sajian dan persembahan yang dapat dibawa pulang dalam bentuk makanan ataupun benda yang tahan lama sebagai kenangan, dan hal itu merupakan bentuk penghormatan masyarakat melayu dalam hal pernikahan (Zainal dan Mit, 2012).

Pengetahuan yang akan ditransfer ke mitra merupakan pengetahuan ketrampilan dalam seni melipat sapu tangan menjadi bentuk_bentuk produk pertanian yang tidak asing lagi di masyarakat. Dan ketrampilan ini bila ditransfer ke masyarakat, diharapkan akan menjadi bernilai dalam menambah pengetahuan dan dalam memanfaatkan waktu luang untuk menghasilkan sesuatu yang bernilai jual (Hodidjah dkk, 2011).

Mitra adalah sekelompok ibu-ibu yang tergabung dalam satu kelompok pengajian yang bernama " Salimah". Kelompok ini beranggotakan ibu-ibu rumahtangga yang tidak memiliki pekerjaan lain selain sebagai ibu rumahtangga.

Kelompok Salimah memiliki banyak aktifitas sosial dalam mengisi kegiatan yang sudah diprogramkan. Salah satu kegiatan yang dicanangkan adalah pelatihan dalam menambah pengetahuan anggota, bidang ilmu yang ditransfer ke anggota Salimah tidak hanya tentang ilmu agama, namun ilmu tentang ketrampilan juga diberikan kepada anggotanya (Surtinah dan Nizar, 2017).

Kesempatan dan waktu yang dimiliki oleh anggota Salimah ini yang akan diberdayakan sehingga waktu luang tersebut bermanfaat dan berdayaguna. Kegiatan ini merupakan kegiatan atas permintaan dari kelompok Salimah, sehingga kegiatan Pengabdian Kepada Masyarakat (PKM) ini menjadi lebih bermanfaat bila dibandingkan dengan kegiatan PKM yang kita tentukan lokasinya. Anggota kelompok Salimah didominasi oleh ibu-ibu dari suku melayu, yang terdiri dari beberapa bidang ketrampilan, salah satunya adalah bidang pelestarian budaya melayu, yang biasanya mengelola catering khusus makanan melayu, dan kue khas melayu. Kelompok Salimah ingin mengembangkan ketrampilan dengan membuat souvenir pengantin yang bercirikan melayu. Di sisi lain kegiatan Tri Dharma Perguruan Tinggi Universitas Lancang Kuning (Unilak) harus mengusung budaya melayu sebagai dasar untuk kegiatan pengabdian masyarakat, selain itu transfer pengetahuan disesuaikan dengan kompetensi bidang ilmu yang dimiliki oleh Tim pelaksana. Kolaborasi antara Perguruan Tinggi dan masyarakat menjadi lebih bermanfaat apabila yang dibutuhkan masyarakat dapat diakomodir oleh Perguruan Tinggi sebagai bentuk solusi yang dibutuhkan masyarakat.

Anggota kelompok Salimah memiliki keinginan untuk menghasilkan sesuatu yang dapat digunakan untuk menambah penghasilan, namun pengetahuan tentang keterampilan tersebut sangat minim sekali. Dengan kegiatan ini diharapakan anggota dapat bertambah pengetahuannya, dan manambah penghasilan keluarganya.

Kelompok Salimah merupakan kelompok yang memiliki usaha seperti koperasi, dimana mereka menampung hasil karya anggota untuk dipasarkan melalui usaha tersebut. Saat ini yang mereka pasarkan adalah hasil dalam bentuk makanan olahan. Sehingga diharapkan juga hasil kegiatan PKM ini dapat memenuhi kebutuhan anggotanya dalam menyediakan souvenir pengantin melayu.

Kabutuhan anggota Salimah dalam membuat souvenir pengantin melayu, di isi dengan ketrampilan yang dimiliki oleh anggota Tim PKM, maka diharapkan akan menghasilkan suatu yang bermanfaat, tidak hanya bagi anggota, tetapi juga bagi pelaksana kegiatan PKM. Dan kegiatan transfer pengetahuan ini juga diharapkan dapat menjadi salah satu kegiatan yang mendukung visi misi UNILAK unggul 2030 berlandaskan budaya melayu. Urgensi kegiatan ini dilakukan adalah untuk menambah keanekaragaman produk ketrampilan dari kelompok Salimah dalam memberikan pelayanan kebutuhan pernak pernik pernikahan, aqiqah, sunatan yang tidak terpenuhi pada saat ada permintaan untuk kegiatan tersebut.

Pemilihan bahan baku berdasarkan pada ketahanan bahan yang digunakan, dan nilai estetika yang tinggi. Adat masyarakat melayu selalu mengutamakan yang terbaik, dan kesungguhan. Sapu tangan handuk dipilih karena tahan lama dan dapat digunakan untuk keperluan lain. Bahan lain yang bisa digunakan seperti kertas dan kain sisa (perca sesuai ukuran) disesuaikan dengan kemampuan penyelenggara acara.

Permasalahan yang dihadapi oleh mitra adalah: 1) Rendahnya pengetahuan tentang cara membuat souvenir pernikahan melayu dengan bentuk produk pertanian. 2) Belum adanya pelatihan tentang ktrampilan membuat souvenir pernikahan melayu dengan bentuk produk pertanian. 3) Keraguan terhadap kemampuan diri sendiri dalam membuat souvenir pernikahan Melayu Riau. Untuk mengatasi permasalahan tersebut maka Tim menyusun cara dalam melaksanakan kegiatan tersebut, antara lain; 1)Peningkatan pengetahuan tentang manfaat membuat souvenir pernikahan. 2) Memberikan pelatihan cara membuat souvenir pernikahan melayu dengan bentuk produk pertanian. 3) Praktek langsung yang dilakukan peserta untuk membuat sendiri souvenir dari saputangan dan membentuknya seperti bentuk produk pertanian. Tujuan yang ingin dicapai dari kegiatan ini adalah : Mitra mampu memodifikasi saputangan ke dalam bentuk produk pertanian yang dapat digunakan sebagai souvenir pernikahan pengantin melayu.

\section{METODE PELAKSANAAN}

Kegiatan PKM ini dilakukan kepada sekelompok mitra yaitu mitra kelompok ibu-ibu kelompok pemgajian salimah , Kelurahan Rumbai dan sekitarnya yang 
anggotanya terdiri dari beberapa RW yang ada di Kelurahan Rumbai.

Metode yang akan dilaksanakan untuk mencapai tujuan adalah :

1) Penyadaran untuk meningkatkan pengetahuan tentang souvenir pernikahan yang dihubungkan dengan ekonomi keluarga.

2) Demontrasi atau Memberikan pelatihan cara memodifikasi saputangan menjadi bentuk produk pertanian, seperti bunga, dan buah yang bernilai jual.

3) Uji coba : kegiatan yang dilakukan dengan memberi kesempatan kepada peserta untuk membuat secara langsung souvenir pernikahan yang sudah didemontrasikan cara pembuatannya.

4) Evaluasi : keberhasilan dari kegiatan PKM diukur dengan menggunakan kuesioner sebelum dan sesudah evaluasi

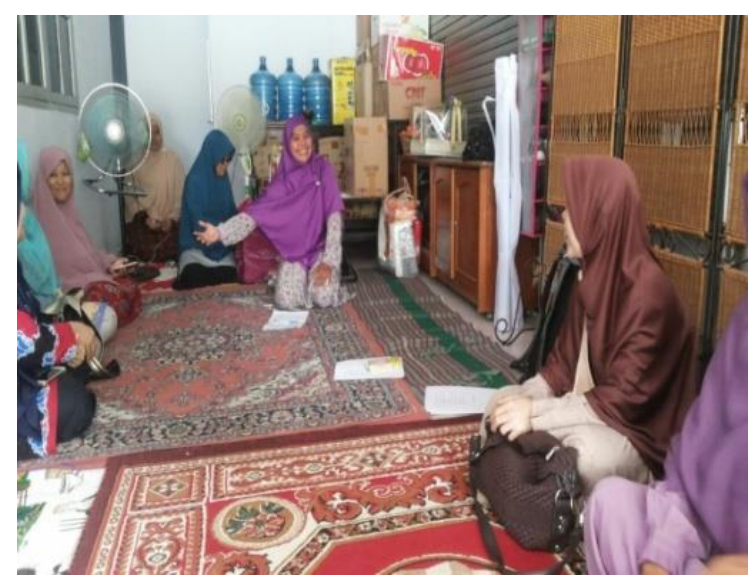

Gambar 1. Ketua Salimah sedang memberikan pengarahan kepada peserta kegiatan

\subsection{Pembahasan}

Kegiatan pengabdian kepada masyarakat ini akan mencapai tujuannya apabila tujuan yang akan dicapai tersebut bisa diukur. Pada kegiatan ini pengukuran hasil kegiatan dilakukan dengan menggunakan instrumen pengukuran yang berupa kuesioner. Kuesioner yang diberikan kepada peserta berupa kuesioner sebelum mengikuti kegiatan dan sesudah mengikuti kegiatan dengan pertanyaan yang sama. Sehingga peningkatan pengetahuan peserta yang menjadi tujuan dari kegiatan ini dapat dilihat.

Peserta yang menghadiri acara PKM ini adalah 32 orang, namun yang mengisi kuesioner sejumlah 25 orang. Hal ini disebabkan karena kehadiran peserta yang tidak serempak, sehingga Tim kewalahan dalam mendeteksi peserta yang terlambat datang. Tetapi dari jumlah kuesioner yang kembali sudah menggambarkan lebih dari $78 \%$ peserta mengisi kuesioner tersebut.

\section{HASIL DAN PEMBAHASAN \\ 3.1 Hasil Kegiatan}

Kegiatan Pengabdian kepada masyarakat ini dilaksanakan pada tanggal 13 Desember 2017, bertempat di rumah salah seorang anggota Salimah, di Jalan Limbungan Gang Cemara Kecamatan Rumbai Pesisir. Kegiatan dimulai pukul 13.30 dan berakhir pukul 15.30 .

Kegiatan pengabdian kepada masyarakat Badan Penjaminan Mutu tersebut dihadiri oleh perwakilan Salimah dari masing-masing RW yang ada di Kelurahan Rumbai, dan jumlah peserta yang hadir adalah 32 orang.

Peserta yang hadir adalah anggota Salimah yang tergabung dalam progran "Sister" yaitu akronim dari Sekolah Ibu-ibu Salimah Terpadu, dimana kelompok ini bertugas untuk belajar dan hasil pembelajaran akan disosialisasikan ke anggota yang lain di kelompoknya masing-masing sesuai dengan RW yang diwakilinya

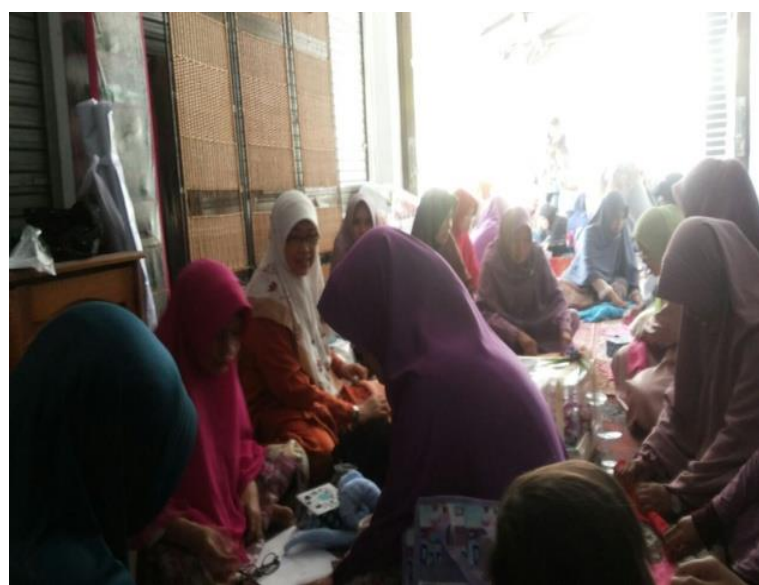

Gambar 2. Ketua Tim PKM sedang memberikan tutorial kepada peserta kegiatan

PKM yang dilakukan oleh BPM mendapat sambutan yang luar biasa dari peserta, dimana pada kegiatan ini BPM menganjurkan kepada peserta untuk membawa alat peraga masing-masing untuk digunakan pada saat uji coba membuat souvenir pernikahan. Seluruh peserta yang hadir membawa alat peraga sehingga pengetahuan tentang memodifikasi saputangan menjadi bentuk produk petanian berjalan dengan baik dan berhasil. Produk-produk pertanian yang di contohkan antara lain adalah bunga mawar, wortel, buah peach, nenas, dan buah pir.

Antusiasme peserta tergambar dari ketekunan mereka mengikuti demontrasi yang diberikan oleh anggota dari Tim PKM. Begitu juga Tim PKM dengan sabar memberikan pelatihan ini sampai peserta dapat menghasilkan bentuk-bentuk produk pertanian yang dimaksud. 
Hasil pengukuran yang berhubungan dengan pengetahuan peserta ditampilkan pada Tabel 3. Dan peningkatan pengetahuan peserta ditampilkan pada Tabel 4.

Tabel 1. Hasil Pengukuran sebelum kegiatn PKM dilaksanakan.

\begin{tabular}{r|l|c|c}
\hline No. & $\begin{array}{l}\text { Kuesioner sebelum } \\
\text { kegiatan }\end{array}$ & $\begin{array}{c}\text { Ya } \\
(\%)\end{array}$ & $\begin{array}{c}\text { Tidak } \\
(\%)\end{array}$ \\
\hline 1 & $\begin{array}{l}\text { Pengetahuan tentang } \\
\text { souvenir pernikahan } \\
\text { Pengetahuan tentang cara } \\
\text { membuat souvenir } \\
\text { pengantin melayu } \\
\text { pengetahuan tentang } \\
\text { souvenir bisa menambah } \\
\text { penghasilan }\end{array}$ & 0,84 & 0,16 \\
5 & $\begin{array}{l}\text { Minat dengan kegiatan } \\
\text { PKM } \\
\text { Minat membuat souvenir } \\
\text { pernikahan } \\
\text { Keyakinan bahwa } \\
\text { dengan pelatihan ini } \\
\text { peserta bisa membuat } \\
\text { souvenir pengantin } \\
\text { Manfaat kegiatan ini } \\
\text { bagi masyarakat } \\
\text { Keinginan membuka } \\
\text { usaha souvenir pengantin } \\
\text { melayu }\end{array}$ & 1,00 & 0,8 \\
\hline
\end{tabular}

Pada umumnya peserta PKM mengetahui tentang souvenir pernikahan pada masyarakat melayu, karena disetiap acara pernikahan souvenir pernikahan akan diberikan sebagai ucapan terimakasih atas kehadiran tamu dalam memenuhi undangan tuan rumah. Dan pada umumnya souvenir pernikahan yang diberikan tidak dalam bentuk modifikasi produk pertanian. Tetapi dalam bentuk yang berbeda.

Bentuk produk pertanian menjadi lebih menarik ditampilkan dengan memodifikasi bahan yang tersedia di pasar. Ketrampilan dalam membuat souvenir pernikahan di kalangan peserta sangat rendah, sehingga diharapkan melalui kegiatan ini ketrampilan tersebut meningkat, karena sangat mudah membuatnya dan tidak membutuhkan peralatan yang banyak. Hanya membutuhkan ketrampilan saja dan kreatifitas seni yang perlu diasah melalui latihan langsung.

Tabel 2. Hasil pengukuran sesudah kegiatan

\begin{tabular}{r|l|c|c}
\hline No. & Kuesioner sesudah kegiatan & $\begin{array}{c}\text { Ya } \\
(\%)\end{array}$ & $\begin{array}{c}\text { Tidak } \\
(\%)\end{array}$ \\
\hline 1 & $\begin{array}{l}\text { Pengetahuan tentang souvenir } \\
\text { pernikahan }\end{array}$ & 1,00 & 0 \\
2 & $\begin{array}{l}\text { Pengetahuan tentang cara } \\
\text { membuat souvenir pengantin } \\
\text { melayu }\end{array}$ & $\begin{array}{l}\text { pengetahuan tentang souvenir } \\
\text { bisa menambah penghasilan } \\
\text { Minat dengan kegiatan PKM }\end{array}$ & 1,00 \\
1,00 & 0 \\
\end{tabular}

\begin{tabular}{c|l|c|c}
5 & $\begin{array}{l}\text { Minat membuat souvenir } \\
\text { pernikahan }\end{array}$ & 1,00 & 0 \\
6 & $\begin{array}{l}\text { Keyakinan bahwa dengan } \\
\text { pelatihan ini peserta bisa } \\
\text { membuat souvenir pengantin }\end{array}$ & 1,00 & 0 \\
\hline 7 & $\begin{array}{l}\text { Manfaat kegiatan ini bagi } \\
\text { masyarakat }\end{array}$ & 1,00 & 0 \\
8 & $\begin{array}{l}\text { Keinginan membuka usaha } \\
\text { souvenir pengantin melayu }\end{array}$ & 1,00 & 0 \\
\hline
\end{tabular}

Setelah kegiatan demontrasi cara membuat souvenir yang dipergakan oleh Tim, maka dapat dilihat kenaikan yang sangat nyata terhadap pengetahuan tentang cara membuat souvenir pernikahan masyarakat melayu tersebut.

Pada Tabel 5. 80\% peserta meningkat pengetahuannya dalam membuat souvenir pernikahan masyarakat melayu tersebut, hal ini merupakan gambaran keberhasilan Tim dalam memberikan pengetahuan dalam memodifikasi saputangan menjadi bentuk produk pertanian.

Kegiatan ini sangat bermanfaat bagi masyarakat untuk meningkatan pengetahuannya dalam bidang ketrampilan, waktu yang banyak tersisa setelah mengurus urusan rumahtangga bila dimanfaatkan untuk kegiatan positif akan menghasilkan sesuatu yang bernilai positif juga. Seluruh peserta sangat menyadari bahwa ketrampilan ini dapat dijadikan sumber penghasilan keluarga. Dan seluuh peserta setelah mengikuti kegiatan ini ingin membuka usaha souvenir pernikahan, karena bahan yang digunakan mudah diperoleh, modal yang diperlukan tidak besar, dan waktu yang digunakan juga tersedia cukup.

Tabel 3. Peningkatan Pengetahuan Peserta setelah mengikuti kegiatan PKM

\begin{tabular}{|c|c|c|}
\hline No. & Kuesioner & $\begin{array}{c}\text { Peningkatan } \\
(\%)\end{array}$ \\
\hline 1 & $\begin{array}{l}\text { Pengetahuan tentang } \\
\text { souvenir pernikahan }\end{array}$ & 0,16 \\
\hline 2 & $\begin{array}{l}\text { Pengetahuan tentang } \\
\text { cara membuat souvenir } \\
\text { pengantin melayu }\end{array}$ & 0,80 \\
\hline 3 & $\begin{array}{l}\text { pengetahuan tentang } \\
\text { souvenir bisa menambah } \\
\text { penghasilan }\end{array}$ & 0,00 \\
\hline 4 & $\begin{array}{l}\text { Minat dengan kegiatan } \\
\text { PKM }\end{array}$ & 0,00 \\
\hline 5 & $\begin{array}{l}\text { Minat membuat } \\
\text { souvenir pernikahan }\end{array}$ & 0,00 \\
\hline 6 & $\begin{array}{l}\text { Keyakinan bahwa } \\
\text { dengan pelatihan ini } \\
\text { peserta bisa membuat } \\
\text { souvenir pengantin }\end{array}$ & 0,00 \\
\hline 7 & $\begin{array}{l}\text { Manfaat kegiatan ini } \\
\text { bagi masyarakat }\end{array}$ & 0,00 \\
\hline 8 & $\begin{array}{l}\text { Keinginan membuka } \\
\text { usaha souvenir } \\
\text { pengantin melayu }\end{array}$ & 0,00 \\
\hline
\end{tabular}


Hasil keterampilan yang dibuat oleh ibu-ibu kelompok "salimah" yang tergabung dalam Bidang "Sister" dikirimkan ke Tim PKM dapat dilihat pada Gambar berikut ini:
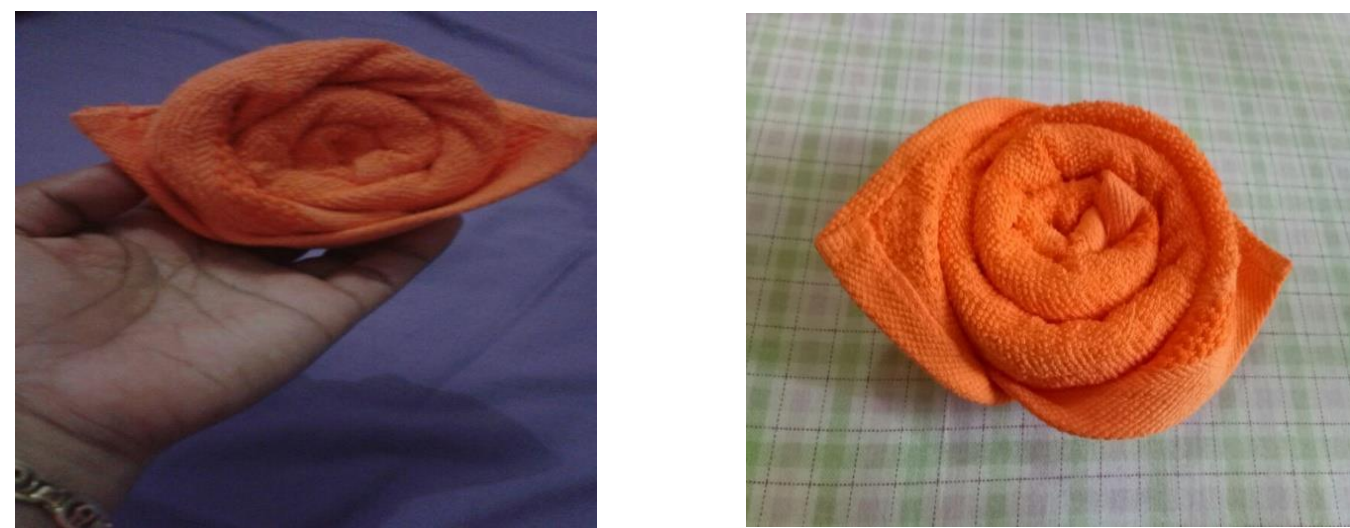

Gambar 1. Saputangan dalam bentuk modifikasi bunga mawar
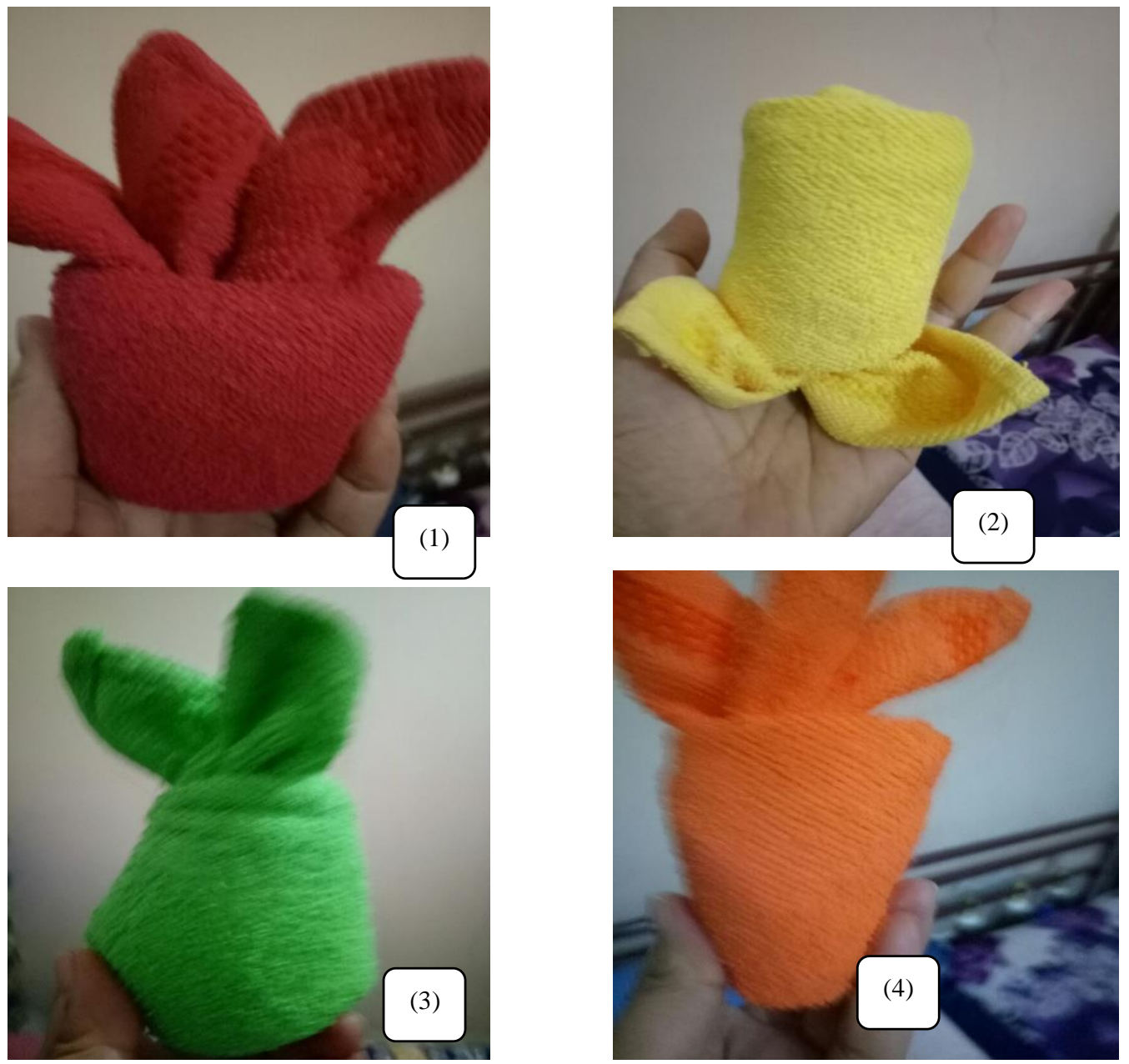

Gambar 2. (1) modifikasi buah peach; (2) modifikasi buah peer; (3) modifikasi nenas; dan (4) modifikasi wortel

Uji coba pengembangan usaha souvenir yang sudah dilakukan oleh ibu-ibu "Salimah" adalah membuat souvenir pernikahan untuk anggota keluarga "Salimah" yang melangsungkan pernikahan, seperti Gambar 3 .

Perhitungan hasil usaha souvenir saputangan handuk yang dilakukan seperti pada Tabel 6. Modal yang digunakan tergantung dari ukuran saputangan, bahan saputangan, dan kemasan produksinya. Semakin besar ukuran saputangan yang digunakan maka harga/satuan akan lebih mahal. Dan hal tersebut tergantung dari pesanan, yang tergantung pula pada kemampuan konsumen. Untuk uji coba ini digunakan saputangan handuk yang berukuran $20 \times 20 \mathrm{~cm}$. 


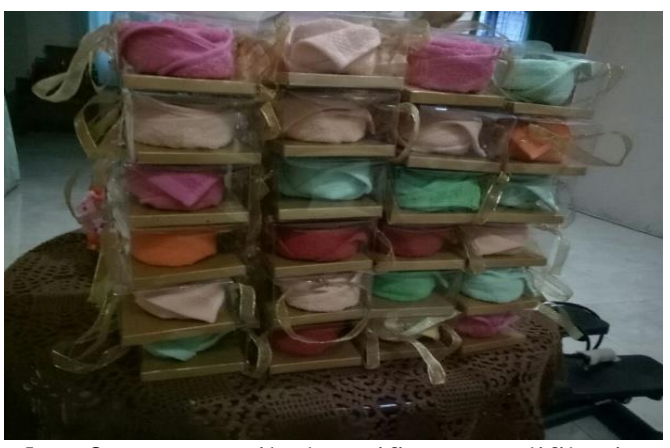

Gambar 3. Hasil kreatifitas modifikasi sapu tangan handuk menjadi bentuk produk pertanian yang siap diberikan ke tamu undangan

Tabel 4. Hasil usaha souvenir modifikasi saputangan handuk menjadi bentuk produk pertanian

\begin{tabular}{|c|c|c|c|c|}
\hline NO & Bahan & $\begin{array}{c}\text { Harga } \\
\text { Satuan } \\
\text { (Rp.) }\end{array}$ & $\begin{array}{l}\text { Harga } \\
\text { / Lsn } \\
\text { (Rp.) } \\
\end{array}$ & $\begin{array}{l}\text { Laba } \\
\text { (Rp.) }\end{array}$ \\
\hline I. & Modal & & & \\
\hline 1 & $\begin{array}{l}\text { Saputangan } \\
\text { Handuk }\end{array}$ & 4.166 & 50.000 & \\
\hline 2 & Kemasan & 2.000 & 24000 & \\
\hline & \multicolumn{2}{|c|}{ Total } & 74.000 & \\
\hline II. & Harga Jual & & & \\
\hline 1 & 1 Bentuk & 7500 & 90000 & 16.000 \\
\hline
\end{tabular}

Dari perhitungan diperoleh keuntungan sebesar Rp. 16.000,-/Lusin. pesanan untuk anggota "Salimah" minimal 100 kotak, sehingga diperoleh pendapatan sebesar Rp. 616.600,-. dan keuntungan yang diperoleh adalah Rp. 134.000,-. Waktu yang dibutuhkan adalah 4 jam. Jumlah yang sangat baik untuk membantu perekonomian keluarga. Dan harga ini adalah untuk harga anggota kelompok, sedangkan bila pemesan yang bukan anggota Salimah maka harga jual bisa ditingkatkan lagi.

Harga souvenir bisa diturunkan lagi apabila wadah souvenir tidak berupa kotak mika, tetapi berupa kantong plastik biasa yang harganya jauh lebih murah dibandingkan dengan kotak mika. Platik biasa satu kantong harganya Rp. 30.000,- isi satu kantong 100 lembar. Jadi untuk 100 souvenir dikeluarkan dana sebesar Rp. 416.600,- + Rp. 30.000,- = Rp. 446.600,dengan harga jual Rp. 6.500,- maka akan diperoleh keuntungan sebesar Rp. 203.400,- dengan waktu yang dibutuhkan adalah 4 jam kerja.

Kegiatan usaha ibu-ibu Salimah ini akan berkembang bila ada kebijakan dari pimpinan Salimah untuk mewajibkan anggotanya membeli minimal 100 souvenir ke kelompok Salimah tersebut, selain bisa menambah uang kas, maka usaha sampingan untuk meningkatkan penghasilan keluarga sesuai dengan visi kelompok dapat tercapai.

\section{KESIMPULAN}

Outcome kegiatan PKM sesuai dengan tujuan kegiatan yang ingin dicapai maka diperoleh hasil sebagai berikut:

a. Setelah mengikuti kegiatan PKM, terjadi peningkatan pengetahuan sebesar $80 \%$ dari peserta.

b. Hasil analisis studi kelayakan untuk produksi 100 souvenir menggunakan kotak mika memperoleh laba usaha sebesar Rp. 134.000,dengan waktu produksi selama 4 jam.

c. Hasil analisis studi kelayakan untuk produksi 100 souvenir menggunakan kemasan plastik memperoleh laba usaha sebesar Rp. 203.400,dengan waktu produksi selama 4 jam.

d. Implikasi riil dan praktis agar usaha souvenir pernikahan masyarakat melayu ini dapat berkembang adalah bila ada kebijakan dari pimpinan Salimah untuk mewajibkan anggotanya membeli minimal 100 souvenir sebagai modal kerja untuk kemudian dipasarkan ke dalam kegiatan khusus yang diadakan didalam maupun diluar daerah setempat.

\section{UCAPAN TERIMAKASIH}

Terimakasih kepada Pimpinan Unilak yang telah memberikan fasilitas baik berupa sarana prasarana PKM, dan alokasi dana dalam melakukan PKM ini, dan terimakasih juga disampaikan kepada Ketua LPPM Unilak yang telah mempermudah pelaksanaan PKM ini.

\section{DAFTAR PUSTAKA}

Hodidjah, Rustono, W., Pranata, O. H., dan Lidinillah, D.A.M., (2011). IbM Kelompok Usaha Pemuda Bidang Kerajinan, Souvenir, Sablon, dan Percetakan. Ciamis.

Sungkowo, B.,(2008). Peran Ragam Hias Tradisional Melayu Riau Pada Desain Produk Kerajinan Kayu di Pekanbaru. J. Vis. Art, 2(3), 197-220.

Surtinah, dan Nizar, R., (2017). Pemanfaatan Pekarangan Sempit dengan Hidroponik Sederhana di Pekanbaru. J. Pengabdian Kepada Masyarakat (JPKM), 23(2), 274-278.

Syahrani, R. P., dan Fatimah, N. (2015). Tunjuk Ajar Melayu Dalam Pantun Adat Perkawinan Melayu Kelurahan Daik Kabupaten Lingga Provinsi Kepulauan Riau. Pekanbaru.

Zainal, R., dan Mit, M., (2012). Citra Riau Takkan Melayu Hilang di Bumi. Dinas Kebudayaan dan Pariwisata Provinsi Riau. Pekanbaru. 